\section{Japanese AIDS scandal over trials and marketing of coagulants}

Tokyo

A SCANDAL has erupted in Japan over the government's handling of applications for clinical trials and marketing of heattreated blood coagulants for haemophiliacs. A former head of the Ministry of Health and Welfare's AIDS (acquired immune deficiency syndrome) research group has admitted delaying approval of clinical trials and marketing so that a Japanese blood-product manufacturer could catch up with foreign competition. As a result, many of Japan's haemophiliacs are thought to have been infected with AIDS.

Japan's first AIDS cases were announced by the ministry in March 1985 but the two patients, both haemophiliacs, had already died, one in 1983. The cases were reported in a medical journal by Dr Takeshi Abe of
Teikyo University who served as head of the ministry's AIDS research group from June 1983 to March 1984. A Tokyo AIDS doctor familiar with the inner workings of the ministry told Nature in 1986 that announcement of the arrival of AIDS in Japan was delayed to "make preparations and avoid public panic". But it seems that more devious reasons lay behind the delayed announcement.

Blood coagulants that have been heattreated to kill viruses such as AIDS were marketed in West Germany in May 1981 and in the United States in March 1983, according to Yukio Yasuda, vice-president of the Tokyo branch of the National Association of Haemophiliacs. In the summer of 1983, the association began a campaign urging the government to introduce the

\title{
UK health research threatened by "oppressive" new contracts
}

\section{London}

Britain's Department of Health and Social Security (DHSS) has incensed recipients of its research contracts by insisting that no results of research financed by the department can be published without permission from the secretary of state. Previously, research contracts required only that any proposed publications be - shown to the secretary of state and that "any comments which the secretary of state makes shall be considered by the researcher but the researcher shall nevertheless be free to allow publication to go forward in the original form as he thinks fit".

The new wording is starkly different. Contracts now stipulate that publication is "subject to the prior consent of the secretary of state, which consent shall not be unreasonably upheld". Institutions and individuals receiving DHSS research contracts warn that the new wording is oppressive and unacceptable and that new contracts will not be signed in their present form. The matter has been taken up by professional bodies, including the Royal Society and the Society for Social Medicine.

The DHSS says that the wording of contracts has been changed merely to satisfy legal requirements for publications whose copyright is vested in the Crown, the previous wording having conferred inadequate control over publication, even when legal advice might have been against publication. To that extent, says the DHSS, there is no change in policy and no intention to restrict or suppress publication.

Researchers argue that it is a principle of academic freedom that is at stake, and that they cannot be expected to conduct research in the knowledge that at the end of the day publication may be censored. More specifically, there are fears that the credibility of DHSS-funded research may be undermined if journal editors or readers do not know if results have been suppressed. Furthermore, the clause will enable the department to delay publication (presently if nothing is heard from the department within 28 days, publication may proceed regardless). Another concern is that under the terms of the new contracts, DHSS-funded workers will find it difficult to find collaborators.

The fact that on its past record there is little to suggest that the department would attempt to interfere with publication is immaterial, say the objectors, who want at the very least to see the contracts contain a more precise form of words that define specific circumstances in which consent to publish can be refused.

Although the question of academic freedom seems unlikely to cut much ice with the government, wider public criticism might. Although most of the health department's externally contracted research (for which it will pay some $£ 16$ million this year) involves politically uncontentious topics, such as hospital design or nursing practice, several programmes (for example, investigations into leukaemia incidence around nuclear power stations, or feasibility studies on contracting services to the private sector) are more sensitive. People are not finding difficulty envisaging circumstances where the government would be grateful for the way that contracts are now worded.

Simon Hadlington use of heat-treated blood coagulants in Japan. But it was two years before the products were allowed on the market. In the interim, hundreds of Japanese haemophiliacs, many of them young boys, are thought to have been infected with AIDS.

It is a characteristic feature of AIDS in Japan that most sufferers are haemophiliacs - by last October, 34 of Japan's 59 officially confirmed AIDS patients were haemophiliacs, 20 of whom have died. Furthermore, 930 of 986 known AIDS virus carriers are haemophiliacs and the ministry estimates that about 40 per cent of Japan's 5,000 haemophiliacs, or 2,000 people, are infected with the AIDS virus. The prime infection route is strongly suspected to have been blood plasma imported from the United States for manufacture of blood coagulants.

So why did the ministry take so long to approve marketing of heat-treated coagulants? The ministry issued guidelines for clinical testing in November 1983. But, according to Yasuda, Abe then controlled everything. He designated the companies to carry out clinical tests and the hospitals where tests were to be performed. And the Mainichi newspaper recently reported that Abe admitted deliberately delaying approval of clinical testing and marketing so that Japan's Green Cross Corporation (Midori Juji) could catch up with companies such as Baxter Trevanol and Bayer and Hoest. Midori Juji dominates Japan's blood-product market.

In his defence, Abe argues that he avoided giving late approval to only one company to prevent arousing suspicions of the safety of the company's products among haemophiliacs. But the Mainichi has also revealed that Abe received a large donation from Midori Juji to set up a nonprofit corporation to promote research on haemophilia. The corporation was founded in July 1986 under Abe's leadership with total funds of $¥ 110$ million $(\$ 850,000)$. And the corporation headquarters is in a two-room apartment in Tokyo's Itabashi-ku, which, according to the landlord, is empty most of the time.

Baxter Trevanol and Bayer Hoest also contributed $¥ 10$ million to Abe's nonprofit corporation. But, according to the Mainichi, one of these foreign companies was at first reluctant to contribute and finally did so only after repeated requests from Abe during the process of trying to get approval for clinical testing. But Abe denies any connection between the funds donated and his control over testing.

The 2,000-member National Association of Haemophiliacs plans to demand compensation from the Ministry of Health and Welfare and the pharmaceutical companies that sold non-heat-treated blood coagulants. But the association has not decided whether to demand compensation from Abe. Yasuda sees as the culprit the whole system. 